\title{
External Relations Management of Malaysia Principals
}

\author{
Bity Salwana Alias ${ }^{1}$, Zaida Nor Zainudin² \\ ${ }^{1}$ Faculty of Education, Universiti Kebangsaan Malaysia, Bangi, Malaysia \\ ${ }^{2}$ Faculty of Education, Universiti Putra Malaysia, Serdang, Malaysia \\ Email: bity@ukm.edu.my, zaidanor@upm.edu.my
}

How to cite this paper: Alias, B. S., \& Zainudin, Z. N. (2018). External Relations Management of Malaysia Principals. Creative Education, 9, 2254-2264.

https://doi.org/10.4236/ce.2018.914166

Received: August 16, 2018

Accepted: October 27, 2018

Published: October 30, 2018

Copyright (c) 2018 by authors and Scientific Research Publishing Inc. This work is licensed under the Creative Commons Attribution International License (CC BY 4.0).

http://creativecommons.org/licenses/by/4.0/

\begin{abstract}
The concept of school management has been extensively studied, however only a few focused on the external relations management. Due to the statement in Malaysian Education Development Blueprint 2013-2025 that school managers are required to build a good collaboration with communities, this study aims to identify principals' competency in managing external relations by measuring their knowledge and skills in those areas. This survey study involved 314 principals, 720 senior assistants, and 611 senior teachers all over Malaysia. The quantitative data were collected through questionnaire and were analyzed by SPSS to determine mean score and standard deviation. Finding shows that, in overall principals' knowledge and skills are at a high level with the mean score 4.27 and 4.40 respectively. Principals' knowledge on external sources that can benefit schools achieves the lowest (mean score 4.23), followed by knowledge on concept of cooperation between school and school/home/community (mean score 4.25), and knowledge on strategy to improve relationship between school and community (mean score 4.25). The lowest mean score for skills is influencing outsiders to contribute to the school fund (4.23), followed by handling criticism in a positive way (mean score 4.37), and showing appreciation to the communities' involvement in school activities (mean score 4.37). This study concludes that principals' competency can be at the best level if knowledge and skill in those aspects can be increased.
\end{abstract}

\section{Keywords}

Education, Principal, Knowledge, Skills, External Relation Management

\section{Introduction}

Management is a social process formed to seek cooperation, participation and 
involvement of members of an organization to achieve one of the most effective goals or objectives (Drucker, 2012). Management also has been defined as the process of conducting an activity efficiently and effectively through human beings. There are nine areas of school management, namely management and organizational leadership, curriculum management, co-curriculum management, student affairs management, financial management, office administration management, environmental and physical facilities management, human resource development management, and external relations management Reference (National Institute of Educational Management and Leadership, Ministry of Education Malaysia, 2006).

The ability of managing external relations management efficiently and effectively, no doubt can contribute to the betterment of the school, yet it is still an area that rarely being a focus to study. Referring to Jeynes (2014), positive, loving relationships between parents and children are important assets that are frequently ignored by educators and researchers, but that might be the most important for student success.

State pressures for schools to be more publicly accountable for their results were observed in the USA by the end of the 1980s (Wills \& Peterson, 1992; Wohlstetter, 1991), and similar initiatives were felt in other countries (Hill Jr., Douglas, Gordon, Pighin, \& Van Velsen, 2003). On the other hand, education reformers have increasingly invested in developing collaborative communities within schools as a central strategy for improving teaching and student learning (Supovitz \& Christman, 2005). This strategy comes in various guises, including small schools, small learning communities, and teacher teams. Several assumptions about how these communities will enhance instruction underlie the push for these more collaborative learning environments.

In Malaysia, there is a growing body of evidence that parental and community involvement in a child's education can make a significant difference in learning outcomes (Ministry of Education, 2013). Malaysia Education Blueprint 2013 2025 stated that to ensure that a student's entire environment is conducive for learning, the Ministry of Education is shifting its focus from schools to building broader learning systems. The Ministry wants to ensure that parents, the community, and the private sector are fully engaged as partners in education. The focus is to harness the comparative advantages of the different parties to deliver quality education in an integrated, effective, and efficient manner. Measures undertaken are include:

- Raising awareness among parents and communities of their role in their children's education;

- Providing guidance to schools to drive the engagement process;

- Linking financial assistance for poor students to improved parental engagement;

- Empowering Parent Teacher Associations or Persatuan Ibu Bapa dan Guru (PIBGs), to play a greater role in supporting parental and community engagement; and 
- Scaling up Trust Schools and other areas for private sector involvement.

The above discussion shows that the awareness of having a good relation with external communities (including parent) has been increased. Educators and researchers start to measure how good the relations are. However not much focus on the school external relations management, therefore this study fills the gap.

\section{Literature Review}

A fourth-generation model of school-family linkages presented by Murphy \& Torre (2014) extends the narrative of school-parent relationships. It highlights 'norms of community' which include care and respect, trust, authentic membership, collective work and shared vision that school leaders can cultivate to promote membership, partnership and ownership. These sorts of relationships are grounded in healthy communication between parents and children, structured home environments and high expectations from parents for children. The model showed that the essential elements will lead first to increased efficacy and capacity for teachers, leaders and parents, and then to positive academic and socio-emotional benefits outcomes for students. It is suggested that building a culture of engagement for parents must become a primary component of the school mission (Figure 1).

According to Leithwood \& Seashore-Louis (2011), district practices are important in determining school leaders' sense of efficacy and their behavior. The relationships of external communities with the performance of the school leaders and school achievement was further explored by Seashore Louis \& Robinson (2012) who suggested that external accountability policy can have a positive impact on the behaviors of school leaders. In these cases, principals internalize the external accountability policies and shape them to the needs that they see in their staff and among their students. Where one or the other of these factors is weak or missing, external accountability policies will not develop the instructional leadership that is needed to bridge state and district policy intentions with improved school performance.

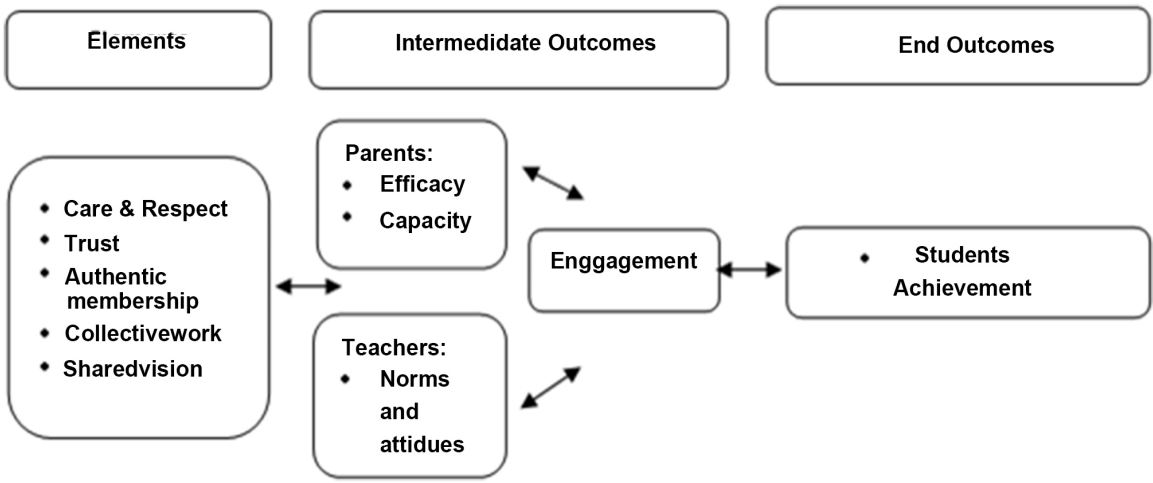

Figure 1. Community of engagement for parents. 
Second, while the survey data suggest that both state and district policies are positively associated with instructional leadership, the case study analysis indicates that the principals who are assessed as effective instructional leaders by their teachers have a nuanced and well-articulated perspective about their district's policy but see the state largely through the lens provided by the district. Their relationship with their districts suggests that they value the district's bridging role because district policies and practices support the alignment of accountability demands and the individual school's student development aspirations. They also value the buffering role and trust that the district will support their efforts to provide the right kind of educational experiences for their students, even when they may be a little risky.

Third, the analysis shows that effective instructional leaders internalize the external accountability policies articulated by both their state and district and shape them to the priorities in their own school. The following are recommended steps to be taken by leaders who want to build communities of instructional practice (Seashore Louis \& Robinson, 2012):

- Focus communities around instruction. District and school leaders need to emphasize those issues by providing communities with tools for systematic inquiry into the relationships between teaching and student learning.

- Diversify communities. Administrators must undertake the difficult work of organizing communities that balance teacher choice, which encourages teacher ownership and engagement, with an equitable distribution of teacher. District and school leaders engaged in forming communities within schools need to learn about instructional communities themselves so that they can then focus the work of these communities on instructional practice.

- Support communities. To support communities of instructional practice, leaders need to provide blocks of protected time in which collaborating teachers can discuss student performance standards and consider how their instruction produces learning.

- Legitimize communities. District and school leaders also need to clarify the authority of community leaders and distinguish it clearly from that of principals. Further, even as they provide guidance about instructional priorities, administrators must allow communities as much autonomy as possible in their decisions about curriculum, staffing, scheduling, and budgets.

- Create professional learning opportunities for communities. Communities of instructional practice require new forms of collaboration, and teachers need professional development experiences that help them learn to work together better.

International evidence from PISA 2009+ indicates that, while parental interest in their child's education is an important first step, the biggest factor driving student performance is how parents spend their time with their child at home (Supovitz \& Christman, 2005). Based on the data, the OECD recently concluded: "The good news is that it does not require a Ph.D. or unlimited hours for parents to make a difference. In fact, many parent-child activities that are associated 
with better reading performance among students involve relatively little time and no specialized knowledge. What these activities do demand, though, is genuine interest and active engagement." Collaborative communities of teachers have great potential for bringing about improvements in teaching and learning.

Referring to Malaysia Education Blueprint 2013-2025, study by OECD showed that students whose parents reported that they read a book with their child "every day or almost every day" or "once or twice a week" during the first year of primary school had higher scores in PISA 2009+ than students whose parents reported that they read a book with their child "never or almost never" or only "once or twice a month". The key now is to ensure these practices happen in every household, making families crucial partners in improving children's learning outcomes.

Blueprint also mentioned that research by Ministry of Education shows that individual schools and school systems that have expanded their focus from parents to the local community have seen a boost in student outcomes. Engaging the community-businesses, non-profit entities, and community organizations-can bring in resources (in the form of funding and access to capabilities) beyond what the public sector may be able to afford. For example, a study by the Centre for Social Organization of Schools in America found that schools that engage with community groups, including businesses, civic organizations, and colleges or universities, enjoyed benefits that included lower student absenteeism, higher rates of homework completion, and higher grades.

Community engagement, especially fund-raising by PIBGs, is not a new practice for Malaysian schools. The Ministry of Education, however, stresses the need for schools to build partnerships centered around the sharing of expertise. In some cases, some schools and communities have developed approaches to improve the delivery of educational services to students.

The blueprint also mentioned that the private sector can also play an important role in delivering on education system aspirations by being a useful supplement to enhance public initiatives and drive greater efficiency in service delivery, including in niche areas. This could be a particularly effective model for groups currently poorly served by traditional delivery methods. For example, the Ministry is piloting a new model for introducing private sector-led innovations in public schools' curriculum, teaching and learning, and overall school management. These are the Trust Schools, with Yayasan AMIR as the private partner.

School principals are responsible to establish good relationships with parents/guardians, outsiders and local communities, to work together as smart partnerships to improve student performance (National Institute of Educational Management and Leadership, Ministry of Education Malaysia, 2006). To ensure the responsibility can be fulfilled, National Institute of Educational Management and Leadership (IAB) has list down the requirements as follows:

Leaders must have knowledge on: 
- National Education Policy, laws and regulations and latest developments.

- A source that can benefit schools.

- Local customs and cross-cultural communities.

- Communication network with all outsiders.

- The concept of interdependence and assisting in helping between school, home and community and establishing cooperation between schools.

- Strategy generation to improve the relationship between school and community.

- The analytical and scientific principles and appraisal techniques and enhancements of external communication management.

Leaders must have the following professional values:

- Trusting in interpersonal skills can help organizational development and external relations management.

- The belief that parents, societies and outsiders are important sources that can be utilized for the good of the school.

- Open minded and can listen as well as the ability to evaluate feedback from the community positively.

- Appreciate outside donations.

Leaders must do the best practices in:

- Establish external relations management policy based on National Education Policy, laws and regulations and latest developments.

- Use external resources to advance schools.

- Consider customs and cross cultures in the management of external relations.

- Establishing a network of relationships with related external parties.

- Practicing the concept of interdependence and assisting in helping between school, home and community and establishing cooperation between schools.

- Implementing strategies to enhance cooperation between schools and the community.

- Conducting ongoing assessment and improvement of external communication management programs.

Research done by Senin, Yusoff, Yusoff, Manaf et al. (2007) showed that school leaders in Malaysia have a low impact competency in external relations, therefore one of the recommendation based on their study is training program to increase school leaders' competency should be regularly and continuously.

\section{Methodology}

This survey study uses questionnaires to collect data. The questionnaires were administered to 314 principals, 720 senior assistants and 611 senior teachers from all over Malaysia (Table 1). The data has been analyzed descriptively using SPSS to determine mean score, which is interpreted by Smith Jr. \& Kuebler (1978) as very low (mean score $\leq 1.50$ ), low (mean score $1.51-2.50$ ), medium 
Table 1. Number of respondent.

\begin{tabular}{ccccc}
\hline Respondent & Population & $\begin{array}{c}\text { Sample } \\
\text { (Krejcie \& Morgan) }\end{array}$ & $\begin{array}{c}\text { Posted } \\
\text { Questionaires }\end{array}$ & $\begin{array}{c}\text { Analysed } \\
\text { Questionaires }\end{array}$ \\
\hline Principal & 2028 & 322 & 444 & 314 \\
Senior Assisant & 6084 & 361 & 1332 & 720 \\
Senior Teacher & 5712 & 357 & 888 & 611 \\
Total & 13824 & 1040 & 2664 & 1645 \\
\hline
\end{tabular}

(mean score $2.51-3.50$ ), high (mean score $3.51-4.50$ ), and very high (mean score $\geq 4.51)$.

\section{Findings}

Based on evaluation by all respondents, principals' knowledge is at a high level with the mean score 4.27 (Table 2).

In depth analysis shows that principals evaluate themselves as having a high level of knowledge in all aspect with the highest score on knowledge for communication network with outsiders (4.43), whereas knowledge on strategy to improve relationship between school and community attains the lowest mean score (4.32). The same result showed by senior assistants and senior teachers' evaluation for the highest mean score that is 4.36 and 4.24 respectively for communication network with outsiders. However, the lowest mean score by senior assistants' evaluation are knowledge on concept of cooperation between school and school/home/community and knowledge on external sources that can benefit schools with the mean score 4.25 for both. Based on senior teachers' evaluation, principals attain a lowest score for knowledge on external sources that can benefit schools with a mean score 4.09. Overall, principals' knowledge on external sources that can benefit schools achieve the lowest (mean score 4.23), followed by knowledge on concept of cooperation between school and school/home/community (mean score 4.25), and knowledge on strategy to improve relationship between school and community (mean score 4.25). As showed in Table 3, overall, principals' skills are at a high level with the mean score 4.40 .

Senior assistants and senior teachers rated principals as having a high skill in all aspects with the mean score 4.42 and 4.27 respectively. However, principals' evaluation showed that their skills are at a very high level with the mean score 4.52. Detailed analysis shows that principals evaluated themselves as having a very high skill in developing a close relationship with parents (mean score 4.56), in establishing a good cooperation with the superior (Ministry of Education/State Education Department/District Education Office) (mean score 4.64), in showing an attitude of welcoming information from outsiders ( $m i n$ score 4.55 ), and in taking advantage of the good things offered by outsiders (mean score 4.53). However, based on subordinates' evaluation, only "skill in establishing a good cooperation 
Table 2. The level of external relations management knowledge of the principals.

\begin{tabular}{|c|c|c|c|c|c|c|c|c|c|c|}
\hline & \multirow{3}{*}{ Knowledge } & \multicolumn{9}{|c|}{ Evaluation } \\
\hline & & \multicolumn{3}{|c|}{ Principal } & \multicolumn{3}{|c|}{ Senior Assistant } & \multicolumn{3}{|c|}{ Senior Teacher } \\
\hline & & Mean & $\mathrm{SD}$ & Lvl & Mean & SD & Lvl & Mean & $\mathrm{SD}$ & $\mathrm{Lvl}$ \\
\hline 1 & $\begin{array}{c}\text { About communication } \\
\text { network with all } \\
\text { outsiders }\end{array}$ & 4.43 & 0.61 & $\mathrm{H}$ & 4.36 & 0.76 & $\mathrm{H}$ & 4.24 & 0.83 & $\mathrm{H}$ \\
\hline 2 & $\begin{array}{l}\text { About strategy to } \\
\text { improve relationship } \\
\text { between school and } \\
\text { community }\end{array}$ & 4.32 & 0.64 & $\mathrm{H}$ & 4.28 & 0.78 & $\mathrm{H}$ & 4.15 & 0.85 & $\mathrm{H}$ \\
\hline 3 & $\begin{array}{c}\text { About concept of } \\
\text { cooperation between } \\
\text { school and } \\
\text { school/home/community }\end{array}$ & 4.37 & 0.63 & $\mathrm{H}$ & 4.25 & 0.80 & $\mathrm{H}$ & 4.14 & 0.85 & $\mathrm{H}$ \\
\hline 4 & $\begin{array}{l}\text { About external sources } \\
\text { that can benefit schools } \\
\text { External relations }\end{array}$ & 4.35 & 0.67 & $\mathrm{H}$ & 4.25 & 0.80 & $\mathrm{H}$ & 4.09 & 0.87 & $\mathrm{H}$ \\
\hline & $\begin{array}{l}\text { management knowledge } \\
\text { in overall }\end{array}$ & 4.37 & 0.56 & $\mathrm{H}$ & 4.28 & 0.72 & $\mathrm{H}$ & 4.16 & 0.78 & $\mathrm{H}$ \\
\hline
\end{tabular}

$\mathrm{H}=$ High, $\mathrm{VH}=$ Very High .

with the superior (Ministry of Education/State Education Department/District Education Office)" achieves a very high level, whereas the others achieve a high level with the mean score between 4.24 to 4.46 . The lowest mean score based on principals' evaluation is skill in handling outsiders influences on decision making (4.46) whereas the lowest mean score achieved by principals based on senior assistants and senior teachers' evaluation is skill in influencing outsiders to contribute to the school fund, mean score 4.31 and 4.16 respectively. Overall, principals' lowest mean score for skills is influencing outsiders to contribute to the school fund (4.23), followed by handling criticism in a positive way (mean score 4.37), and showing appreciation for the communities' involvement in school activities (mean score 4.37).

\section{Research Implication and Recommendation}

Based on research findings, principals' external relations management knowledge and skill are at a high level. This finding is against (Senin, Yusoff, Yusoff, et al., 2007) that competency in external relations of school leaders in Malaysia still at a low level. Even though this study isn't focus on the compulsory training that principals must attend before being elected, the findings showed that training organized by National Institute of Educational Management and Leadership, Ministry of Education Malaysia (2006) and goal stated by Ministry of Education (2013) regarding collaboration with communities does have a positive impact on principals' external relations management. Mean score achieved by principals, whether for knowledge or skills, that is at least at a high level indicates that principals able to manage external relations efficiently and effectively. The findings 
Table 3. The level of external relations management skill of the principals.

\begin{tabular}{|c|c|c|c|c|c|c|c|c|c|c|}
\hline & \multirow{3}{*}{ Skill } & \multicolumn{9}{|c|}{ Evaluation } \\
\hline & & \multicolumn{3}{|c|}{ Principal } & \multicolumn{3}{|c|}{ Senior Assistant } & \multicolumn{3}{|c|}{ Senior Teacher } \\
\hline & & Mean & $\mathrm{SD}$ & Lvl & Mean & $\mathrm{SD}$ & Lvl & Mean & $\mathrm{SD}$ & Lvl \\
\hline 1. & $\begin{array}{l}\text { Handling outsiders } \\
\text { influences in school } \\
\text { decision making }\end{array}$ & 4.46 & 0.62 & $\mathrm{H}$ & 4.39 & 0.73 & $\mathrm{H}$ & 4.28 & 0.79 & $\mathrm{H}$ \\
\hline 2. & $\begin{array}{l}\text { Developing a close } \\
\text { relationships with parents }\end{array}$ & 4.56 & 0.57 & VH & 4.42 & 0.73 & $\mathrm{H}$ & 4.24 & 0.81 & $\mathrm{H}$ \\
\hline 3. & $\begin{array}{l}\text { Influencing outsiders to } \\
\text { contribute to school fund }\end{array}$ & 4.47 & 0.63 & $\mathrm{H}$ & 4.31 & 0.79 & $\mathrm{H}$ & 4.16 & 0.87 & $\mathrm{H}$ \\
\hline 4. & $\begin{array}{c}\text { Establishing a good } \\
\text { cooperation with the } \\
\text { superior (Ministry of } \\
\text { Education/State Education } \\
\text { Department/District } \\
\text { Education Office) }\end{array}$ & 4.64 & 0.55 & $\mathrm{VH}$ & 4.56 & 0.66 & $\mathrm{VH}$ & 4.38 & 0.78 & $\mathrm{H}$ \\
\hline 5. & $\begin{array}{l}\text { Handling criticism in a } \\
\text { positive way }\end{array}$ & 4.48 & 0.60 & $\mathrm{H}$ & 4.41 & 0.70 & $\mathrm{H}$ & 4.23 & 0.78 & $\mathrm{H}$ \\
\hline 6. & $\begin{array}{l}\text { Showing an attitude of } \\
\text { welcoming information } \\
\text { from outsiders }\end{array}$ & 4.55 & 0.58 & $\mathrm{VH}$ & 4.45 & 0.69 & $\mathrm{H}$ & 4.28 & 0.81 & $\mathrm{H}$ \\
\hline 7. & $\begin{array}{c}\text { Taking advantage of the } \\
\text { good things offered by } \\
\text { outsiders }\end{array}$ & 4.53 & 0.60 & $\mathrm{VH}$ & 4.46 & 0.71 & $\mathrm{H}$ & 4.30 & 0.74 & $\mathrm{H}$ \\
\hline 8 & $\begin{array}{l}\text { Demonstrating an attitude } \\
\text { of appreciation for external } \\
\text { involvement in school } \\
\text { activities }\end{array}$ & 4.49 & 0.61 & $\mathrm{H}$ & 4.38 & 0.73 & $\mathrm{H}$ & 4.25 & 0.80 & $\mathrm{H}$ \\
\hline & $\begin{array}{c}\text { External relations } \\
\text { management skill in overall }\end{array}$ & 4.52 & 0.48 & $\mathrm{VH}$ & 4.42 & 0.63 & $\mathrm{H}$ & 4.27 & 0.72 & $\mathrm{H}$ \\
\hline
\end{tabular}

$\mathrm{H}=$ High, $\mathrm{VH}=$ Very High .

support Jeynes (2014); Leithwood \& Seashore-Louis (2011); Murphy \& Torre (2014); Seashore Louis \& Robinson (2012) and Supovitz \& Christman (2005), that the era of close collaboration between school and communities has becomes a practice.

However, with the change in technology and to cope up fast development of all sources, this study recommends that principals should open to a lifelong learning. Management knowledge and skills need to be updating, especially on concept of cooperation, external sources that can benefit schools, and in influencing outsiders to contribute to the school fund. Not only for themselves, principals must also lead subordinates to learn new tools and/or method to enhance good relationship with communities (schools, parents and superior). This is since school can't stand alone, support from Ministry of Education Malaysia, State Education Department, District Education Office, and all community are crucial for the betterment of the school. The close relationship with top management and communities will ease the task of the principal. A close relationship 
with community will encourage contribution to the school.

\section{Conclusion}

This study has successfully explained principal's knowledge and skill in external relations management which determined to be at least at a high level in all aspects. Notwithstanding, principals should aim for continuous professional development and practice lifelong learning to improve their ability in managing school external relations. The principal can increase their competency in managing external relations if they can increase knowledge on strategy to improve relationship between school and community, knowledge on concept of cooperation between school and school/home/community, knowledge on external sources that can benefit schools, skills in handling outsiders influences on school decision making, and skill in influencing outsiders to contribute to school of the fund.

\section{Conflicts of Interest}

The authors declare no conflicts of interest regarding the publication of this paper.

\section{References}

Drucker, P. (2012). The Practice of Management. Abingdon-on-Thames: Routledge.

Hill Jr., R. W., Douglas, J., Gordon, A., Pighin, F. H., \& Van Velsen, M. (2003). Guided Conversations about Leadership: Mentoring with Movies and Interactive Characters. In $I A A I$ (pp. 101-108).

Jeynes, W. (Ed.). (2014). Family Factors and the Educational Success of Children. Abingdon-on-Thames: Routledge. https://doi.org/10.4324/9781315877426

Leithwood, K., \& Seashore-Louis, K. (2011). Linking Leadership to Student Learning. Hoboken, NJ: John Wiley \& Sons.

Ministry of Education (2013). Malaysia Educational Development Plan (PPPM) 2013-2025. Putrajaya: Ministry of Education.

Murphy, J., \& Torre, D. (2014). Creating Productive Cultures in Schools: For Students, Teachers, and Parents. Thousand Oaks, CA: Corwin Press.

National Institute of Educational Management and Leadership, Ministry of Education Malaysia (2006). The Competency Standards of Malaysian School Headship. Genting Highlands: Ministry of Education Malaysia.

Seashore Louis, K., \& Robinson, V. M. (2012). External Mandates and Instructional Leadership: School Leaders as Mediating Agents. Journal of Educational Administration, 50, 629-665. https://doi.org/10.1108/09578231211249853

Senin, A., Yusoff, R., Yusoff, S., Manaf, A. R., Abd Halim, R., Ahmad, R. K., Hassan, R., Abd Rahman, S., Nor, M. Y. M., \& Singh, M. (2007). Monograph: High Impact Competency for School Leaders in Malaysia. Genting Highlands: National Institute of Educational Management and Leadership, Ministry of Education.

Smith Jr., H., \& Kuebler, R. R. (1978). The Importance of Beta, the Type II Error and Sample Size in the Design and Interpretation of the Randomized Control Trial: Survey of 71 Negative Trials. New England Journal of Medicine, 299, 690-694. 
https://doi.org/10.1056/NEJM197809282991304

Supovitz, J. A., \& Christman, J. B. (2005). Small Learning Communities that Actually Learn: Lessons for School Leaders. Phi Delta Kappan, 86, 649-651. https://doi.org/10.1177/003172170508600905

Wills, F. G., \& Peterson, K. D. (1992). External Pressures for Reform and Strategy Formation at the District Level: Superintendents' Interpretations of State Demands. Educational Evaluation and Policy Analysis, 14, 241-260.

Wohlstetter, P. (1991). Accountability Mechanisms for State Education Reform: Some Organizational Alternatives. Educational Evaluation and Policy Analysis, 13, 31-48. https://doi.org/10.3102/01623737013001031 